\title{
1. Greed, accountability and say on pay
}

Regulations introduced by the UK government in $2002^{1}$ and legislation introduced by the Australian government in $2004^{2}$ aimed to improve board accountability for executive remuneration practices within listed companies, in an effort to curb excessive remuneration payments. Both jurisdictions adopted the same regulatory solution: a mandatory remuneration report within the annual report and a mandatory annual advisory vote at the annual general meeting (AGM) of the company to 'adopt' the report. ${ }^{3}$ The initiatives of 2002 and 2004 did not occur in a vacuum, but were a natural progression from earlier attempts to address the same challenges. These new legislative initiatives were promulgated into a 'regulatory space' ${ }^{4}$ that was already rich with attempts to influence executive remuneration accountability and practice. They would only 'work' to the extent that they mobilised and held accountable the existing players in that space to change remuneration practices: institutional shareholders, remuneration consultants, boards of directors of listed (quoted) companies and their remuneration committees. In making laws on executive remuneration, governments in liberal economies such as the UK and Australia walk a policy tightrope: whether to allow company boards to exercise their powers of management free from government constraint, or to choose to regulate this conduct to address the general public's concern with executive greed.

Evidence of this policy tightrope is found in government reform approaches since the early 1990s. The Modern Company Law Review (UK) found a need to strengthen the best practice framework for executive remuneration developed from the Cadbury, ${ }^{5}$ Greenbury ${ }^{6}$ and Hampel ${ }^{7}$ reports. The spirit of Greenbury, of a de minimis framework of listing rules and best practice, was designed to give companies flexibility to adopt and adapt practices to suit the company's specific circumstances. The government was content to support this 'spirit' provided best practice was seen to be working. ${ }^{8}$ It became increasingly frustrated with the prominent attention given to the quantum of directors' remuneration in the press, not to mention the failure of some companies to adopt the Combined Code's guidance. ${ }^{9}$ A 1999 report for the Department of Trade and Industry (DTI) 
recommended new rules to ensure remuneration committees explained their remuneration policies and made full disclosure of all elements of individual directors' remuneration: ${ }^{10}$ a departure from Cadbury's approach of limited named disclosure for the chairman and highest paid UK director only. ${ }^{11}$ Legislation to underpin best practice guidance was necessary to achieve what best practice guidance alone could not - 'increased transparency, strengthened accountability and more effective linkage between pay and performance and the competitiveness benefits this brings'. ${ }^{12}$ The UK government was not willing to dismantle the largely principles-based framework for regulating remuneration practice even though there was evidence to suggest companies were non-compliant.

Of these initiatives, it is the Greenbury Committee that considered the factors and techniques necessary to regulate executive remuneration. The two important factors that combined to regulate executive remuneration were board responsibility (the membership and tasks of the remuneration committee) and shareholder monitoring; with two regulatory techniques needed: disclosure, to improve the transparency of remuneration practices (the obligations to disclose all elements of remuneration) and, secondly, giving shareholders voting rights for remuneration decisions. It considered, and rejected, a vote on the committee's report on remuneration as a standard AGM item of business. Instead the committee endorsed shareholder approval of policy when circumstances warranted that approval should be sought. ${ }^{13}$ This vote was only in relation to remuneration policy, not the policy and outcomes now disclosed in the directors' remuneration report. A shareholder vote to approve all share-based incentive plans (irrespective of whether new shares were issued or not) was recommended, ${ }^{14}$ with the London Stock Exchange (LSE) amending its listing rules to this effect from 1 July 1996.

Many of the same elements seen in the current regulation of executive remuneration in the UK existed from 1996: best practice guidance in a code, listing rules that mandated disclosure of compliance with that code and shareholder guidance on share plans all contributed to a regulatory framework within which remuneration practices happened, but within which authority for ensuring the rules were followed by companies was shared. Greenbury recognised that the plethora of rules, especially multiple sources of shareholder guidance with incompatible positions on the best remuneration practices, ${ }^{15}$ created difficulties for companies.

Australia too considered how to improve executive remuneration practices in a series of corporate governance initiatives in the 1990s. Yet successive federal governments were tentative in using their legislative powers to improve remuneration disclosure. Up until the 1998 reforms, the Corporations Law only required banded disclosure of income received 
by the directors in excess of $\$ 100,000$ for the financial period in the notes to the accounts; ${ }^{16}$ although it was possible to link remuneration levels with particular directors by a series of guesstimates. ${ }^{17}$ Consideration of these provisions by the Parliamentary Joint Committee on Corporations and Securities in 1996 and 1998 led to new mandatory disclosure of remuneration for each director and each of five 'named officers'. ${ }^{18}$ Within three weeks of the bill passing in both houses, the provisions were referred to the Parliamentary Joint Committee on Corporations and Financial Services for review. ${ }^{19}$

While Australia has demonstrated a willingness to adopt what it perceives as international best practice, ${ }^{20}$ the policy goals underpinning legislative initiatives respond to local frustrations and pressures. The change of government position from 2002 (no need for reform of executive remuneration disclosure rules) ${ }^{21}$ to 2003 (remuneration disclosure needed urgent reform) cannot be solely explained by the findings of the HIH Royal Commission in 2003, although the findings were significant. Justice Owen noted several failures in corporate governance at HIH, including capture of the human resources (HR) committee by the chief executive; ${ }^{22}$ and questionable remuneration practices including the absence of criteria to award bonus payments, retrospective salary adjustments, ${ }^{23}$ plus sizeable golden hellos (sign-on bonuses) and termination payments. ${ }^{24}$ His recommendations surrounding remuneration practices ${ }^{25}$ prompted the formation of the ASX Corporate Governance Council and the release of the principles of corporate governance and best practice. ${ }^{26}$

Another corporate insolvency drew a quicker legislative response from the government, as it responded to the outrage created by the payments of million dollar bonuses to the directors of One.Tel Limited just prior to the company's insolvency. ${ }^{27}$ The additional factor prompting a coalition government to act was the political pressure exerted by the opposition parties - the Australian Labor Party, assisted by the Australian Democrats and the Greens - which generated the moral pressure for a change to remuneration norms. The stated objectives of the reform to introduce say on pay (the Corporate Law Economic Reform Program No. 9 - or CLERP 9 as it is known) were to promote transparency, accountability and shareholder activism, ${ }^{28}$ with the remuneration report and advisory vote 'designed to enhance transparency and accountability in relation to decisions surrounding director and executive remuneration' ${ }^{29}$ Achieving the framework principles of remunerating responsibly and fairly ${ }^{30}$ through these legislative measures ${ }^{31}$ requires shareholders to have sufficient information to monitor company remuneration and engage with remuneration committees to translate this broad principle into appropriate, company-specific practices. 
The events that trigger public outrage and the policy goals behind government responses leading to the introduction of say on pay in the UK and Australia illustrate how challenging it is for governments to achieve the correct tension on the policy tightrope. The event triggering public angst is media reporting of executive greed. What is not so clear is how further transparency through disclosures in a remuneration report and an advisory vote on that report reduce executive greed and hence public outrage.

\subsection{CURBING EXECUTIVE GREED}

Greed: it's one of the seven deadly sins. And one of the most cited reasons by governments to justify meddling in company affairs by regulating executive remuneration. The political rhetoric of the global financial crisis (GFC) elevated this sin from the kind of garden-variety greed that you or I might indulge in occasionally to Extreme Greed, ${ }^{32}$ practised by bankers in an unrestrained manner. Yet many inquiries and academics seemed to excuse such behaviour by focusing on the structure of the financial institution incentive schemes ${ }^{33}$ rather than blaming the individuals who, being 'rational economic actors', adjusted their behaviour to maximise their returns.

The wrong performance incentives can create significant problems, as the findings of Lord Turner in 2009 on the causes of the global financial crisis as they relate to banks and bank-like institutions note:

It is nevertheless likely that past remuneration policies, acting in combination with capital requirements and accounting rules, have created incentives for some executives and traders to take excessive risks and have resulted in large payments in reward for activities which seemed profit making at the time but subsequently proved harmful to the institution and in some cases, the entire system. ${ }^{34}$

Politicians were more critical of the individuals but blamed non-executive directors on remuneration committees, 'all too willing to sanction the ratcheting up of remuneration levels for senior managers whilst setting relatively undemanding performance targets'. ${ }^{35}$

This contemporary rhetoric of executive greed did not begin with the global financial crisis. Part of the recent moral panic surrounding executive remuneration in the UK can be traced to the 1990s when high amounts of remuneration were paid despite poor company or individual executive performance. The archetypal 'fat cat' in the early 1990s was Cedric Brown, $\mathrm{CEO}$ of the newly privatised British Gas, who received a substantial pay 
rise in 1994, just one year after privatisation had occurred. ${ }^{36}$ Large scale job losses that marked his period in management fuelled public ire at the increases. ${ }^{37} \mathrm{He}$ was not alone: payments made to executives in other privatised utilities were also flagged by Sir Richard Greenbury as problematic. ${ }^{38}$ However, fat cats were to be found in other listed companies: Tim Holley as CEO of Camelot plc ${ }^{39}$ and the directors of Glaxo Wellcome plc $^{40}$ were among other directors whose pay was seen to be excessive. The Labour Party's platform for the 1 May 1997 general election in the UK included a policy against fat cats,${ }^{41}$ although the government did nothing concrete towards implementing this policy once elected to office. It is therefore unsurprising to read contemporary newspaper reports noting some company boards continued to reward senior executives with excessive remuneration. ${ }^{42}$ Share options started to appreciate in value because of market sentiment surrounding the shares, rather than any evidence of improved performance. ${ }^{43}$

Around the time of the DTI's policy pronouncements in the new millennium, the size of remuneration payments was still attracting media attention. ${ }^{44}$ The second consultative document released in 2001 noted that the regulations would 'underpin a framework in which there is more effective dialogue between companies and investors'. ${ }^{45}$ Thus the new disclosure and voting requirements were directed at improving shareholders' capacity to engage in meaningful micro-level 'regulatory conversations ${ }^{\text {' } 6}$ with remuneration committees. It seems the government expected shareholders to address the issue of fat cats or excessive remuneration quantum as part of this regulatory conversation. In the first year of the new regime shareholders appeared willing to do $\mathrm{so}^{47}$ by targeting companies with contracts that would pay out over two years' base salary and bonus (the performance conditions being effectively waived), supported by the DTI's 'Rewards for failure' inquiry. ${ }^{48}$

The Australian version of this policy goal is found in two distinct policy goals. As noted above, the CLERP 9 reforms adopted the principle espoused by the ASX Corporate Governance Council: remunerate responsibly and fairly. Remunerating responsibly and remunerating fairly are two separate principles that take issue with the quantum of remuneration. As high level principles, however, they provide little concrete guidance to remuneration committees or investors on absolute levels of pay. Instead they focus on relativities and cost-benefit analyses. Responsible remuneration can be determined by assessing the costs and benefits of the remuneration, 'the sensitivities of significant payments to key executives', ${ }^{49}$ and the structure of remuneration payments and termination payments. Responsible remuneration balances fixed and incentive pay and does not focus too much on short term performance; while termination 
payments are to be agreed in advance with 'a clear articulation of performance expectations'. ${ }^{50}$

A principle of remunerating fairly begs the question: to whom should the remuneration be fair? Should this be fair to the executive, fair to the company or fair to the shareholders? By what criterion should fairness be assessed? Is 'fair' an absolute or a relative term? If it is a relative term, how should such relativities be assessed: by reference to externalities (the labour market for similar senior executives), intra-firm (the rate of senior executive remuneration relative to the level of wages and salaries paid to the ordinary rank and file employees), ${ }^{51}$ or both $?^{52}$ Is this criterion of fairness referenced to company performance rather than other remuneration, so that pay for performance should be construed not only in terms of a linkage but a fair link? In other words, give a fair year's pay for a fair year's performance?

High levels of remuneration can readily satisfy the need to be 'responsible' if the benefit to the company is that a skilled senior executive stays (retention payment) or that the company can hire the best executive talent in a tight labour market (golden hello). Paying a higher bonus in a year with a higher profit than the previous year would probably satisfy the need for fairness. Thus as norms of remuneration practice remunerating responsibly and fairly appear to be management friendly, or at least so vaguely worded as to be capable of multiple meanings and interpretations.

A further policy goal noted in the CLERP 9 documentation was that there should be no excess payments. This policy goal is linked with the principle of 'remunerate fairly' - in other words, there is an upper bound on remuneration that should be attached to particular company and executive performance outcomes. ${ }^{53}$ Australian courts have traditionally been reluctant to define 'excessive' remuneration. ${ }^{54}$ In part, this reluctance reflects the view that the courts take in relation to breaches of the director's duty of care: namely that courts should not try to 'second-guess' the directors' decisions, nor should there be an appeal on the merits of directors' decisions to the courts. ${ }^{55}$ In a similar vein, it has been noted that the court's duty is not to punish 'unsuccessful entrepreneurial activity'. ${ }^{56}$ The courts are more likely to focus on the decision-making process in terms of whether the directors have exercised the requisite standard of care rather than whether they made the right decision or whether they should have reached a different decision. ${ }^{57}$

Definitions of 'reasonable' remuneration appear similarly imprecise, although the payments which can be labelled 'reasonable' seem generous. ${ }^{58}$ The definition of 'reasonable remuneration' in respect of related party transactions under Chapter 2E of the Corporations Act 2001 (Cth) 
requires an assessment of reasonableness of the quantum of remuneration by reference not only to the circumstances of the public company but also to the circumstances of the related party recipient (including the responsibilities involved in the office or employment). ${ }^{59}$ Reasonable remuneration is therefore context specific by company and by the individual manager. If the boundary between reasonable and excessive remuneration cannot be defined with precision because it is context specific, a policy goal of curbing excess remuneration is difficult to satisfy system-wide because it can only be assessed at the level of the individual executive within the individual firm.

While there have been many instances of remuneration excesses over the last ten years to which politicians have responded, passing many new laws on executive remuneration, none of the rules go so far as to say in effect, 'Don't pay $\$ x$ to your executives: that's too much money.' Is this pragmatic law making? Or does it reflect the influence of companies over the form and content of these laws? As Julia Black notes, 'Rules are bargained over and they are built. ${ }^{60}$

\subsection{IMPROVING ACCOUNTABILITY FOR EXECUTIVE REMUNERATION DECISIONS}

Improving director accountability is the other most cited reason for regulating executive remuneration, with a focus on the role of the remuneration committee. Various reform committees convened during the 1990s in the UK emphasised board accountability for executive director remuneration. ${ }^{61}$ Through a combination of high level principles on the overall aims of executive remuneration, together with more detailed guidance on the aims and tasks of the remuneration committee and guidance on the terms of executive service contracts, the Cadbury Committee initially, ${ }^{62}$ and subsequently the Greenbury Committee ${ }^{63}$ and the Hampel Committee, ${ }^{64}$ all sought to improve board policy- and decision-making processes. Alongside these industry-led initiatives, the two major shareholder representative bodies in the UK, the Association of British Insurers (ABI) and the National Association of Pension Funds (NAPF), released guidelines on best practice executive remuneration, having done so since the $1960 \mathrm{~s} .{ }^{65}$ Yet collectively these selfregulatory and shareholder initiatives ultimately failed to achieve the better remuneration practices in listed companies that they described, prompting the UK government to impose a legislative solution to address these failures. ${ }^{66}$

Australian attempts in the early 1990s to improve board accountability 
for remuneration practices also focused on remuneration committees. ${ }^{67}$ The ASX consulted on corporate governance practices endorsed by the Working Group on Corporate Practices and Conduct, chaired by Henry Bosch (the Bosch Committee) in 1994, some two to three years after their introduction. Concerned at the poor response by companies to the Bosch Committee's guidelines, ${ }^{68}$ the ASX promulgated a new listing rule requiring companies to report on a list of corporate governance practices, including remuneration. ${ }^{69}$ One year later, the ASX claimed that listed companies had 'broadly adopted' the board committee structures endorsed in the listing rules. This was soon contradicted by widely reported empirical evidence. ${ }^{70}$

Institutional shareholders were also active in releasing relevant guidance, with the Australian Investment Managers' Association (AIMA) releasing guidance on remuneration committees, the aims of remuneration policy and disclosure in $1995 .{ }^{71}$ Soon after, the AIMA and the Australian Institute of Company Directors (AICD) produced a set of guidelines for executive share option schemes; albeit with the disclaimer that the existence of the guidelines was not to be taken as a representation that members of either organisation 'are bound to act in accordance with it'. ${ }^{72}$ This need to rule-make was to fill a void in the regulatory framework that mandatory remuneration disclosures simply did not address. Despite the efforts of the Bosch Working Group, AIMA and even the AICD, selfregulatory initiatives were unable to deliver better remuneration practices. The government interpreted evidence of poor practices as an absence of proper accountability by boards of directors, justifying the government acting to do so via legislative means.

\subsection{INCREASING THE LEVEL OF SHAREHOLDER ENGAGEMENT}

The particular resolution in both jurisdictions is to 'adopt' the remuneration report, not to approve particular remuneration policies or practices, or the remuneration decisions made in light of these policies. A substantial vote against the remuneration report does not reveal any clear area of concern by shareholders. As with accountability, more engagement was seen as an end in and of itself. Both governments were for most of the first decade of the new millennium content to allow the funds management, superannuation and pension industries to self-regulate on the issue of engagement and voting. Listed companies are clearly not the only parties bargaining keenly with governments over the rules that should govern their activities. 


\subsubsection{UK Debate on Shareholder Engagement}

Shareholder engagement was the focus of a separate line of inquiry begun in 1995 with the release of Developing a Winning Partnership ${ }^{73}$ and the Myners Review of Institutional Investment over the period 1999 to $2001 .{ }^{74}$ Although occupational pension funds are the predominant institutional investors in the UK, ${ }^{75}$ most engagement is undertaken by their external fund managers. Myners noted that fund managers were generally reluctant to actively engage with underperforming investee companies. ${ }^{76} \mathrm{He}$ thought they should take an active role in engagement: if fund managers justified receiving high fees because of their skill in reviewing company strategy and operations as part of the investment decision, Myners believed they were also capable of making judgments about whether to intervene in these matters and how best to do so. ${ }^{77}$ Furthermore, he found no evidence that the prohibitions on parties acting in concert in the Takeover Code 78 had ever been invoked during the course of an intervention to prevent fund managers combining their efforts to collectively engage with company management. ${ }^{79}$ Thus a small individual shareholding was not a reason not to engage: it was a reason to collaborate with other institutional investors to do so.

Other factors explain this apathy: if the key performance indicator for clients is the last quarter's performance figures, the basis for selecting fund managers and their fee structures offers little incentive to intervene in companies to make changes on a longer time scale. ${ }^{80} \mathrm{With}$ a culture that seeks to avoid conflict, ${ }^{81}$ and numerous real potential conflicts of interest, ${ }^{82}$ many fund managers chose not to pursue active engagement and intervention policies. ${ }^{83}$ They could, but there was no obvious financial gain from doing so. Myners believed that engaging with investee companies is to further the client's best interests, not to fulfil a public interest obligation. ${ }^{84}$ This means that a regulatory design that relies on shareholders to fulfil public interest obligations such as curbing executive greed depends upon fund managers agreeing that this would further their clients' interests. While Myners did not see the overriding requirement to act in the client's best interests as curtailing engagement, it is arguably a real constraint upon any role institutional investors can play within the regulated remuneration cycle to achieve policy goals that are not linked with the financial performance of the investment. If engagement with a company could potentially culminate in a decline in that company's share price (because the engagement becomes public and undermines market confidence, or else executive dissatisfaction results in poor performance), institutional investors will choose either not to engage or may sell their shares instead. ${ }^{85}$

Separately, a further barrier to institutional investor voting was said 
to be the problems with the mechanics needed to vote by proxy. ${ }^{86}$ The Modern Company Law for a Competitive Economy initiative was well aware of the issues surrounding vote execution, especially where beneficial owners could not exercise voting rights. ${ }^{87} \mathrm{~A}$ behavioural shift by institutional investors to embracing voting as a fiduciary responsibility was needed and noted at the time. ${ }^{88}$ The main focus, however, of the various voting inquiries beginning with the Newbold Inquiry and continuing with the reviews commissioned by the Shareholders' Working Group was on the complex chain of voting instructions between the beneficial owner and the fund manager. This chain evidently worked efficiently when corporate decisions relating to the investment were made, such as the decision to take up entitlements in a rights issue. ${ }^{89}$ Clearly some other measure was needed to encourage institutional investors to exercise their voting rights.

The perceived need to strengthen shareholder engagement was due to the failure of the regulatory framework to deliver remuneration that matched Greenbury's fundamental principles of accountability, transparency and a clear link between pay received and performance. ${ }^{90}$ Shareholders were to play an important role in putting into practice the government's proposed reforms on transparency and shareholder powers of control. ${ }^{91}$ Yet the government, fully aware of a number of shortcomings with shareholders' records on engagement and voting, was persuaded to maintain the self-regulatory nature of these crucial activities.

\subsubsection{Australian Debates on Shareholder Engagement}

CLERP 9 reforms adopting such a non-binding advisory resolution on pay reflect an expectation that shareholders want to become involved in remuneration issues and more shareholder involvement will improve the accountability of directors. ${ }^{92}$ Parliament contemplated the role of institutional shareholders in company affairs as part of the 1998 reforms to remuneration disclosure noted above, in the process rejecting a move to introduce compulsory voting by institutional investors. ${ }^{93}$ The Companies and Securities Advisory Committee, CASAC, inquiring into shareholder participation one year later considered, but rejected, non-binding advisory resolutions on company management as blurring the 'fundamental' distinction between the roles of the board of directors in company management and that of shareholders. ${ }^{94}$

Weighing against the prospects of improving director accountability via engagement were the historically low levels of proxy voting in Australia. A study based on proxy-voting levels in a sample of 59 major Australian listed companies in the year 1999, including 40 widely held companies, ${ }^{95}$ reported that proxy instructions represented an average 35 per cent of 
total voting capital. ${ }^{96}$ The authors noted that this compared less favourably with the UK (50 per cent for a sample from the FTSE 350 in 1999) ${ }^{97}$ and the USA (around 80 per cent). ${ }^{98}$ Data presented to the Parliamentary Joint Committee on Corporations and Financial Services reported that the level of proxy voting among 161 widely held ASX companies in 2003 was 44 per cent of all equity with voting rights. ${ }^{99}$ However, a 2003 study of shareholder activism by the Investment and Financial Services Association (IFSA) showed that 91 per cent of the fund managers surveyed reported they were routine voters, who voted on at least 90 per cent of all resolutions put forward by investee companies. ${ }^{100}$

If fund managers were largely complying with their voting obligations as this latter evidence suggests, the presence of large numbers of retail and foreign shareholders on the share register might explain the low voting rates reported in the first mentioned study. Mandating institutional investor voting was debated in Australia as part of the reforms to the company legislation in 2004 without any changes being made to mandate either voting, disclosure of voting policy or disclosure of voting practice. ${ }^{101}$

\subsection{WHY SAY ON PAY APPEARS AN IDEAL ANSWER}

Say on pay as introduced in 2002 in the UK and 2004 in Australia achieves the right tension on the policy tightrope: it satisfies the need for governments to be seen to be acting to address executive greed and poor remuneration practices, while respecting the integrity of the board of directors' decision-making processes: the mandatory annual vote by shareholders is only advisory. Indeed mandated disclosure and advisory votes strengthened the measures taken by institutional investors and market exchange operators to address executive remuneration in the 1990s, rather than presenting a radical departure from such approaches. Corporate governance codes in the 1990s emphasised the role of the remuneration committee, while offering some high level principles for remuneration practices. Institutional shareholder guidance supplemented these codes by describing in detail best practice remuneration. That new regulatory tools in the form of a mandatory remuneration report and advisory vote were deployed in 2002 and 2004 indicate that these earlier strategies, which were supposed to facilitate the principals' exercise of control over their agents, were not sufficient to ensure 'good' remuneration practices. What role would these earlier strategies and regulatory actors play with the introduction of say on pay?

The stated rationale for legislative intervention in both jurisdictions was 
to improve board accountability for remuneration practices. Shareholders could diligently monitor remuneration practices if governments mandated particular remuneration disclosures that made both the remuneration policy and payments transparent. Shareholders could then engage with those remuneration committees making bad remuneration decisions, voting against the remuneration report to send an unequivocal signal when private engagement failed to secure a commitment to change practices. Governments further expected that these legislative measures would make the pay for performance alignment stronger and that there would be no further remuneration excesses or examples of irresponsible remuneration payments (such as termination payments that rewarded failure). Thus the underlying rationale for government intervention is better executive remuneration practices in listed companies. Remuneration payments that are clearly aligned with performance would confirm this policy goal had been achieved. High levels of remuneration were acceptable provided performance warranted that level of payment.

With its 'feedback loop' of the advisory vote, say on pay improves upon previous disclosure-only initiatives: any lack of credibility in the remuneration and performance disclosed provides the occasion for shareholder engagement in the period leading up to the AGM. Creating the conditions for shareholder action is an important aim of these reforms, but relies on shareholders responding to the opportunities created. The advisory vote preserves the sanctity of the board of directors within listed companies. It also fits with institutional shareholder reluctance to undertake actions that may negatively impact on their investment: the legislation clearly states that the outcome of the vote does not affect the remuneration of any director. ${ }^{102}$ Rather than strengthening shareholder engagement (and thus the practices that listed companies adopt), the advisory vote could undermine these policy goals if institutional investors treat engagement and voting as alternatives in practice, and prefer voting on an advisory vote to engagement and voting.

The advisory vote might also make no difference to practices - the ultimate outcome that say on pay seeks to achieve - if shareholders' tolerance for ever increasing levels of executive remuneration in investee companies is high, or if their resolve to tackle poor practices wanes in the glare of strong corporate performances, a bull market and high dividend yields.

\section{NOTES}

1. Directors' Remuneration Report Regulations 2002 (UK) SI 2002/1986.

2. Corporate Law Economic Reform Program (Audit Reform and Corporate Disclosure) 
Act 2004 (Cth), schedule 5, item 14 (disclosure) and schedule 5, item 7 (advisory vote).

3. In this way, the advisory vote differs from shareholder proposals studied in Ertimur, Ferri and Muslu 2010; Renneboog and Szilagyi 2011; Cziraki, Renneboog and Szilagyi 2010; Ertimur, Ferri and Stubben 2010. See Cheffins and Thomas 2001 for a preliminary discussion on these differences.

4. Scott 2001, p. 329.

5. Committee on the Financial Aspects of Corporate Governance 1992a and 1992b.

6. Study Group on Directors' Remuneration 1995.

7. Committee on Corporate Governance 1998.

8. Department of Trade and Industry 1998 [3.7].

9. Department of Trade and Industry 2001a, pp. 4, 13.

10. PricewaterhouseCoopers and the Department of Trade and Industry 1999, para. [ii].

11. Committee on the Financial Aspects of Corporate Governance 1992b, p. 7.

12. Department of Trade and Industry 2001b, para. [11].

13. Study Group on Directors' Remuneration 1995, pp. 15, 32.

14. Study Group on Directors' Remuneration 1995, pp. 16, 42. The previous listing rules only required shareholder approval if the share plan involved the issue of new shares.

15. Study Group on Directors' Remuneration 1995, p. 42.

16. Corporations Regulations 1990 (Cth), schedule 5, cl 25(2).

17. Defina, Harris and Ramsay 1994, p. 349.

18. Company Law Review Act 1998 (Cth) amended s 300 and inserted s 300A into the Corporations Law.

19. Joint Committee on Corporations and Securities 1999, pp. 1-3; Hudson and Shield 1998; Henderson 1998.

20. Joint Committee on Corporations and Financial Services 2004, p. 86.

21. Department of Treasury, Commonwealth of Australia 2002.

22. Owen 2003, pp. 282-3.

23. Owen 2003, pp. 283-96.

24. Owen 2003, pp. 301-8.

25. Owen 2003, p. lxv.

26. ASX Corporate Governance Council 2003.

27. Corporations Amendment (Repayment of Directors' Bonuses) Act 2003 (Cth) inserted a new voidable transaction into the insolvency provisions in the Corporations Act 2001 (Cth). These provisions allow a liquidator to apply to the court to declare void a director-related transaction entered into within four years of the day on which the winding up of the company commenced.

28. Joint Committee on Corporations and Financial Services 2004.

29. Corporations Law Economic Reform Program (Audit Reform and Corporate Disclosure) Bill 2003 (Cth), Explanatory Memorandum, p. 166.

30. ASX Corporate Governance Council 2003, p. 51.

31. Joint Committee on Corporations and Financial Services 2004, p. 33.

32. Rudd 2008.

33. Congressional Oversight Panel 2009, pp. 38-9; Institute of International Finance 2009, pp. 1-2; Organisation for Economic Cooperation and Development 2009b, pp. 16-18; Financial Services Authority 2009, pp. 79-80; Braithwaite 2009, p. 444; Crotty 2009, p. 565; Ciro and Longo 2010, pp. 16-17; Bebchuk and Spamman 2010, pp. 255-68; Committee on Oversight and Government Reform 2008, pp. 74-7.

34. Financial Services Authority 2009, p. 80.

35. Treasury Committee, House of Commons 2009, p. 3.

36. Nelson, Calvert and Woolf 1995; Dickson 1995.

37. Sweeney 1995.

38. Study Group on Directors' Remuneration 1995, pp. 9, 49-52; Department of Trade and Industry 2000a, p. 61; Lewis 1996; Cragg and Dyck 2003, pp. 187-91.

39. Cassell 1996; Chancellor 1997. 
40. Donovan and Whitebloom 1997.

41. Unknown 1996; Barnett 1997; Labour Party 1996.

42. Unknown 1997a; Elliott 1998.

43. Laurance 1997; Barnett 1998; Parker 1998; Jackson 1998a, 1998b.

44. Most notable of these was Sir Christopher Gent as CEO of Vodafone ple who received a $£ 10$ million transaction bonus on the acquisition of Mannesmann AG: Dickson 2000.

45. Department of Trade and Industry 2001a, p. 13.

46. Black 2002.

47. Sheehan 2007.

48. Department of Trade and Industry 2003.

49. Department of Trade and Industry 2003, p. 53.

50. Department of Trade and Industry 2003, pp. 55-6.

51. Shields, O'Donnell and O'Brien 2003, pp 1-2.

52. ASX Corporate Governance Council 2003, p. 55. Fixed remuneration is recommended to be set at a level that is 'reasonable and fair, taking into account the company's legal and industrial obligations and labour market conditions, and should be relative to the scale of the business. . [reflecting] core performance requirements and expectations'.

53. Joint Committee on Corporations and Financial Services 2004, p. 42.

54. Hill 1996, p. 233; Hill 2006, pp. 71-4.

55. Harlowe's Nominees Pty Ltd v Woodside (Lakes Entrance) Oil Co NL (1968) 121 CLR 483 at p. 493; Howard Smith Ltd v Ampol Petroleum Ltd [1974] AC 821 at p. 823. The authors of Ford's Principles of Corporations Law note that this principle is subject to statutory provisions that permit the court to review directors' decisions on the merits: Austin and Ramsay 2010, pp. 377-8.

56. Australian Securities and Investments Commission v Rich (2009) 75 ACSR 1 at pp. 611-12. For an example of a completion bonus payment to the director approved by that director in breach of his duties as a director, see Diakyne Pty Ltd ( ACN 099168 402) v Ralph and Another (2009) 72 ACSR 450 at pp. 467-79 (upheld on appeal: Ralph $v$ Diakyne Pty Ltd (ACN 099168 402) [2010] FCAFC 18, at [27]-[32]).

57. Australian Securities and Investments Commission v Rich (2009) 75 ACSR 1 at p. 623 .

58. Defina, Harris and Ramsay 1994, pp. 342-45.

59. Corporations Act 2001 (Cth), s 211(1)(b).

60. Black 1995, p. 96.

61. Filatotchev et al 2006, p. 55; Cheffins 1997, pp. 374-6.

62. Committee on the Financial Aspects of Corporate Governance 1992b, pp. 7, 10 (especially note 9 on membership of the remuneration committee). Adoption of the Code was seen not only to establish best practice but also to encourage shareholder pressure so as to ensure its principles would be quickly adopted: Committee on the Financial Aspects of Corporate Governance 1992a, p. 52; Department of Trade and Industry 2000 a, p. 66 (especially note 85 ).

63. Study Group on Directors' Remuneration 1995.

64. Committee on Corporate Governance 1998.

65. Stapledon 1996, p. 74.

66. Seidl 2007, pp. 707-9; Dine 2006, pp. 76-8.

67. Working Group on Corporate Practices and Conduct 1991, p. 14; Working Group on Corporate Practices and Conduct 1992, pp. 14, 26. Working Group on Corporate Practices and Conduct 1995.

68. Australian Stock Exchange 1994, pp. 4, 6.

69. Australian Stock Exchange, Listing Rules, r 3C(3)(j). An indicative list of practices was set out in Appendix 33 and included disclosure of 'the main procedures for establishing and reviewing the compensation arrangements for the Chief Executive Officer and other senior executives', as well as the remuneration of the board of directors. 
Companies were required to report on this for annual reporting periods ending on or after 30 June 1996.

70. Ramsay and Hoad 1997, pp. 454-5, 457, 465; Gluyas 1997a, 1997b; Unknown 1997b; Blue 1998.

71. Australian Investment Managers' Association 1995, p. 6 (guideline 11, disclosure of quantum and components of each director's remuneration together with the same information for each of the five highest paid executives, including the details of the CEO's service contract); p. 22 (recommended practice on board and executive remuneration policy and on disclosure). Since its inception in 1995 to the present day, this publication has been known as the Blue Book.

72. Australian Investment Managers' Association and the Australian Institute of Company Directors 1994, [3].

73. Myners 1995.

74. Myners Review of Institutional Investment for HM Treasury 2001.

75. Myners Review of Institutional Investment for HM Treasury 2001, p. 5.

76. Myners Review of Institutional Investment for HM Treasury 2001, p. 11.

77. Myners Review of Institutional Investment for HM Treasury 2001, p. 90.

78. City Code on Takeovers and Mergers (UK), Rules 9.1(a) and (b).

79. In 2009, the Panel released guidance on its interpretation of the Code rules which stated that the prohibitions on acting in concert will not preclude the kind of activity Myners envisaged: Panel on Takeovers and Mergers 2009, paras [1.2], [1.4]. There are several other problems with forming a coalition, including the risk of the engagement becoming public knowledge (which can lead to a share price decline): Keay 2007, pp. 660-1.

80. Myners Review of Institutional Investment for HM Treasury 2001, p. 91.

81. This explains why engagement activities such as interventions start out as covert activities: Stapledon 1996, p. 127; Lamming et al 2004, p. 30.

82. Myners Review of Institutional Investment for HM Treasury 2001, p. 91. The main type of institutional investor prone to such conflicts of interest is fund management firms within banking or insurance groups which have commercial relationships with FTSE 100 companies. For suggestions on reform, see Ingley and van der Walt 2004, pp. 545-6; Short and Keasey 1997, pp. 35-8.

83. Department of Trade and Industry 2000b, pp. 71-3.

84. Department of Trade and Industry 2000b, pp. 11, 90; Institutional Shareholders' Committee 2002, p. 2.

85. Stapledon 1996, p. 128.

86. National Association of Pension Funds 1999.

87. Department of Trade and Industry 2000a, pp. 85-9.

88. Department of Trade and Industry 1999c, p. 19.

89. Myners 2004, p. 12.

90. Department of Trade and Industry 1999a.

91. Department of Trade and Industry 2001c, pp. 55-6, 58-9. Trade and Industry Committee, House of Commons (UK) 2003, paras [111]-[19].

92. Corporations Law Economic Reform Program (Audit Reform and Corporate Disclosure) Bill 2003 (Cth), Explanatory Memorandum, p. 170.

93. Companies and Securities Advisory Committee 2000, pp. 63-6.

94. Companies and Securities Advisory Committee 2000, p. 38.

95. The study's authors defined a company as widely held if no shareholder held more than 20 per cent of the issued ordinary share capital: Stapledon, Ramsay and Easterbrook 1999, p. 19.

96. Stapledon, Ramsay and Easterbrook 1999, p. 20.

97. Pension Investment Research Consultants Ltd, Proxy Voting Trends 1999, cited in Stapledon, Ramsay and Easterbrook 1999, p. 21.

98. Stapledon, Ramsay and Easterbrook 1999, pp. 26-7.

99. Joint Parliamentary Committee on Corporations and Financial Services, Commonwealth of Australia, Committee Hansard, Canberra, 9 March 2004, p. 16 
(Sandy Easterbook, Corporate Governance International, CGI, a proxy advisory firm).

100. Investment and Financial Services Association and KPMG 2003, p. 2. At that time IFSA members held around 25 per cent of the ASX by market capitalisation: p. 8 .

101. Chapple and Cheung 2005, p. 81.

102. Companies Act 2006 (UK), c 46, s 439(5), formerly Companies Act 1985 (UK), c 6, s $241 \mathrm{~A}(8)$. 